\title{
IAMJ
}

INTERNATIONAL

AYURVEDIC

MEDICAL JOURNAL

Case Report

ISSN: 2320-5091

Impact Factor: 6.719

\section{CASE REPORT: CLINICAL MANAGEMENT OF KATIGATVATA WSR TO PIVD}

\author{
$\underline{\text { Monika Das }}^{1}$, Pradeep Madhur ${ }^{2}$
}

Reader Panchkarma Department, SAMCH, Indore, Madhya Pradesh, India

Lecturer Panchkarma Department, SAMCH, Indore, Madhya Pradesh, India

Corresponding Author: dasmonika16@gmail.com

\section{https://doi.org/10.46607/iamj15p5062021}

(Published online: September 2021)

\section{Open Access}

(C) International Ayurvedic Medical Journal, India 2021

Article Received: 16/08/2021 - Peer Reviewed: 31/08/2021 - Accepted for Publication: 05/09/2021

\section{Check for updates}

\section{ABSTRACT}

In India, nearly $80 \%$ of people have significant back pain due to lumbar pathology. In this case study patient's main complaint was severe low backache, stiffness in the back due to which he was unable to do his routine activities. He was diagnosed with Prolapsed intervertebral disc (PIVD) which can be correlated to katigatvata (low backache) which comes under vatavyadhi. Panchkarma therapies like katibasti and panchtikta ksheer basti in kala basti format are given with oral vatashamak medicines. In course of treatment satisfactory improvement was noted.

Keywords: Katigatavata, Vatavyadhi, Katibasti, PTKB.

\section{INTRODUCTION}

More than 10 million cases of PIVD are found per year in India. Young adults (14-40), adults (41- 60 years) and seniors (60 +years) are very commonly affected with a male to female ratio of $2: 1$.

Any situation which increases pressure within a disc can lead to damage and prolapse. Lifting heavy objects, fall or injury may change the disc. A sudden increase in pressure on the disc causes a tear in the tough outer ring. If the tear extends right through the outer ring, some of the soft centres may prolapse. As well as local pressure on the nerve from the disc there is swelling and inflammation. This inflammation is responsible for severe pain caused by disc prolapse. 
Katigatvata can be considered under Vata Vyadhi (musculoskeletal and neurological diseases). In this Katishool is there and pathogenesis of katishoola (low backache) is asthipradoshaj, degeneration of bony tissue in kati (lumbosacral region) due to vitiation of vata.

Line of Treatment of Vata Vyadhi is abhyanga (massage), swedana (fomentation) basti (medicated enema) and nivaat sthana (resides in a warm place). So, these lines of treatment were adopted for katishoola.

Kati Basti is external therapy that causes localized Snehan and Swedan. In this lukewarm oil is poured on the lower back which is held by a small frame. Muscles of that area get relaxed and due to qualities of oil and also due to the gradual pressure effect of pooled oil, local changes may occur in the intervertebral area.

Charak and Vaghbhatta mentioned the use of basti prepared with tikta dravyas, ksheer and ghrita as treatment of asthigata dosha (bony tissue) along with the use of swayoni dravyas (similar substances).

Sushruta also mentioned similar substances in the case of diminished dhatus.

\section{CASE REPORT:}

A male patient of age 29 years from Badwani visited OPD of Shubhdeep Ayurved Medical College and Hospital, Indore.

$\mathrm{C} / \mathrm{O}-1)$ Severe low backache for last 2 months.

2) Stiffness in the back and can't bend forward for the last 2 months.

3) Difficulty to squat -1 month.

\section{H/O PRESENT ILLNESS -}

The patient was asymptomatic 2 months before, gradually he developed low backache and that become severe with no history of any trauma or injury. There was stiffness in the lower back, and he couldn't bend forward. He took allopathic treatment but did not get any relief, so he came to our hospital.

\section{Clinical Findings -}

SLR - The straight leg raising (SLR) test was $40^{*}$ on the right leg and $45^{*}$ on the left leg.

VAS - 6

Diagnostic Assessment -

MRI lumb sacral region - Focal Annualar disc bulge at L4 - L5 and L5 - S1, livel causing thecal sac indentation with no nerve root compression.

Table 1: Assessment Criteria

\begin{tabular}{|c|c|c|c|}
\hline S.No & Symptoms & Parameters & Gradation \\
\hline 1 & Pricking pain & $\begin{array}{l}\text { Absent } \\
\text { Mild } \\
\text { Moderate } \\
\text { Severe }\end{array}$ & $\begin{array}{l}0 \\
2 \\
4 \\
6\end{array}$ \\
\hline 2 & Stiffness & $\begin{array}{l}\text { Absent } \\
\text { Mild } \\
\text { Moderate } \\
\text { Severe }\end{array}$ & $\begin{array}{l}0 \\
2 \\
4 \\
6\end{array}$ \\
\hline 3 & SLR Scoring & $\begin{array}{l}0 \\
10 \\
20 \\
30 \\
40 \\
50 \\
60 \\
70 \\
80 \\
90\end{array}$ & $\begin{array}{l}54 \\
48 \\
44 \\
36 \\
30 \\
24 \\
13 \\
12 \\
6 \\
0\end{array}$ \\
\hline 4 & VAS & $\begin{array}{l}\text { No Pain } \\
\text { Mild Pain } \\
\text { Moderate Pain } \\
\text { Severe Pain } \\
\text { Very severe }\end{array}$ & $\begin{array}{l}0 \\
1-3 \\
] \\
] 4-6 \\
]\end{array}$ \\
\hline
\end{tabular}




\begin{tabular}{|l|l|l|l|}
\hline & & Worst pain possible & $7-9$ \\
\hline 5 & Posture & $\begin{array}{l}\text {-No Complaints } \\
\text {-Patient walks without diffi- } \\
\text { culty but experiences diffi- }\end{array}$ & 10 \\
\hline & $\begin{array}{l}\text { culty getting up from squat- } \\
\text { ting }\end{array}$ & 2 \\
\hline & -Difficulty to squat & 3 \\
\hline & -Difficulty in Climbing stairs & 4 \\
\hline
\end{tabular}

Table 2: Observations are to criteria of assessment Before \& After treatment.

\begin{tabular}{|l|l|l|l|}
\hline S.No & Symptoms & Before Treatment & After Treatment \\
\hline 1 & Pricking Pain & 6 & 0 \\
\hline 2 & Stiffness & 4 & 0 \\
\hline 3 & SLR Scoring RT & 30 & 6 \\
\hline 4 & SLR Scoring LT & 33 & 12 \\
\hline 5 & Posture & 2 & 1 \\
\hline 6 & VAS & 5 & 2 \\
\hline
\end{tabular}

\section{Treatment Planned}

Shodhana Chikitsa - The patient planned for panchkarma therapy in 2 steps:

1) Kati Basti (a procedure where specific medicated oil is retained for a period of time around 30 minutes) in Kati region with Sahachar oil with abhyang and Nadi Sweda on kati region for 5 days.

2) Then the patient is treated with Kala Basti (therapeutic enema with a group of 16 enema) of Panchatikta Ksheer Niruha Basti and Anuvasan Basti (oil enema) with Rasna dashmooladi oil before application of abhyang with MNT and nadi swedan of kati region.

\section{Shamana Chikitsa}

1) Maharasnadi kwatha $30 \mathrm{ml} \mathrm{BD}$ empty stomach twice a day.

2) Brihat Vatachintamani ras $125 \mathrm{mg} \mathrm{BD}$ with honey.

3) Tryodashang guggulu $250 \mathrm{mg} \mathrm{BD}$ with hot water.

4) Tab Shallaki IBD.

\section{RESULT}

The general condition of the patient becomes fair. There is $85 \%$ relief in Chief Complaints of the patient. No adverse effect of therapy was seen.

\section{DISCUSSION}

The line of treatment given for vatvayadhi is adopted for Katishool (low backache) Kati Basti (specific medicated lukewarm oil is poured on the lower back or specific time which is held by a small frame). It is external therapy that causes localized snehan and swedan which acts against the ruksha gun (dryness) and Sheeta guna (coldness) of vata. The properties of sahacharadi tail such as Snigdha, Guru, and Ushna are Vata Shamak. It encourages muscle health by nourishing the muscle fibres, regulates muscle function by acting against inflammation. Its phytochemical composition has a relaxing and soothing effect on tendons and ligaments.

Charak Vaghbhatta mentioned the use of basti prepared with tikta dravyas, ksheer, and ghirta in asthigata dosha (bony tissue) along with the use of swayoni dravyas (similar substances). Sushruta also mentioned similarly in diminished dhatus.

Probable mode of action of Panchatikta ksheer basti.

Vata dosha is predominantly present in asthi datu and joints by Ashraya - ashrayi phenomenon ksheer has Snigdha and Madhura properties which do shaman of Vata Dosha. Here ksheer was prepared 
with tikta rasa which is said to be effective in Asthigata and Majjgata rogas.

Basti dravyas contain Madhu, Saindhav, Ghrita and Bala Tail. Madhu contains sucrose and many more enzymes. Saindhava contains $\mathrm{Nacl}$ and other ions which generate action potential by which ion exchange take place through the membrane of the intestine. This exchange of ions may help in - taking out vitiated doshas mainly vayu from the body. Ghrita is Snigdha guna pradhan which can control vitiated Vata dosha due to its properties. Bala tail has antiinflammatory and Tridoshshamak properties.

Brhadvataintamani rasa was used in treatment is indicated in all types of Vataja Vikara, Trayodasanga Guggulu is useful in Snayugatvata (various tendon and ligament disorders), asthigatvata (disorders of bone), majjagatvata (disorders of the bone marrow). Maharasnadi Kashyam is used in Vata disorders like low back pain, osteoarthritis, neck pain etc. The main content is Guggulu, which Ushna veerya and Katu Vipak. Ushna guna is considered as Vatashamak and Vednasthapana.

\section{CONCLUSION}

Combine Therapy of kati basti with Sahachar oil, Panchtikta ksheer basti, Brihatvatachintamiani rasa, Trayodashanga guggulu, Maharasnadi kwath, are effective in the management of katigatvata (PIVD). There is no adverse effect found in course of treatment.

\section{REFERENCES}

1. Singh SK Rajoria k. Ayurvedic approach for management of ankylosing spondylitis. A case report $\mathrm{J}$. Ayurveda Integ. Med. (2016) http://dx.doi.org/10.1016/j.jaim2015.10.002[Pub Med].

2. Tiwari Swati Management of Low Backache due to PIVD through Panchkarma. A case study, Int.J.Res. Ayurveda Pharm. DOI:10.7897/2277-4343.09117

3. Singh S.K. Rajoria k, clinical study on lakshadi guggulu and Panchatikta ksheer basti in osteoarthritis of knee joint, Journal of AYUSH: Ayurveda, Yoga, Unani, Siddha, and Homeopathy 2014:3:4:70p
4. Vaghbhatta Astanga Hridyam edited by Arundata, Sutra, Sthana Doshadi Vijinaniya Adhyaya, Chapter II verse 31. $1^{\text {st }}$ ed Varanasi: Krishnadas Academy; 2000 P 187

5. Sushruta Samhita, Nibandhsangraha commentary of Sri Dalhanacharya with Hindi commentary by Vaidya Yadavji Trikamji Acharya and Narayan Ram Acharya Edition: $4^{\text {th }}$ Sutra Sthana, Dosha dhatumala Vridhiksaya Vijnaneeyam, Chapter 15 verse 8, Varanasi; Chaukhambha Orientalia; 1980 P.68

6. Agnivesha Charak Samhita, Revised by Charaka and Dridhabala with the Ayurved Dipika Commentary of chakrapanidatta edited by Vaidya Yadavji Trikamji Acharya, Chaukhambha Sanskrit Sansthan, $5^{\text {th }}$ edition Varanasi 2001, Sutrasthan, Vatavyadhi Chikitsa adhyaye chapter 28 verse 33 .

7. Agnivesha Charak samhita, Rensed by Charaka and Dridhabala with the Ayurved Dipika Commentary of chakrapanidatta edited by Vaidya Yadavji Trikamje Acharya, Chaukhambha Sanskrit Sansthan, $5^{\text {th }}$ edition Varanasi 2001, Sutrasthan, Vatavyadhi Chikitsa adhyaya chapter 28 verse $104-106$.

8. Agnivesha Charak samhita, Rensed by Charaka and Dridhabala with the Ayurved Dipika Commentary of chakrapanidatta edited by Vaidya Yadavji Trikamje Acharya, Chaukhambha Sanskrit Sansthan, $5^{\text {th }}$ edition Varanasi 2001, Sutrasthan, Vatavyadhi Chikitsa adhyaya chapter 28 verse 27.

9. Sushruta Samhita, Nibandhsangraha commentary of Sri Dalhanacharya with Hindi commentary by Vaidya Yadavji Trikamji Acharya and Narayan Ram Acharya Edition: $4^{\text {th }}$ Sutra Sthana, Dosha dhatumala Vridhiksaya Vijnaneeyam, Sushruta chapter 15 verse 14 Varanasi; Chaukhambha Orientalia; 1980 P.68.

\section{Source of Support: Nil Conflict of Interest: None Declared}

How to cite this URL: Monika Das \& Pradeep Madhur: Case Report: Clinical Management Of Katigatvata Wsr To Pivd. International Ayurvedic Medical Journal \{online\} 2021 \{cited September 2021\} Available from: http://www.iamj.in/posts/images/upload/3143_3146.pdf 